\title{
PREVENTION AND REHABILITATION OF HAMSTRING INJURY IN FOOTBALL PLAYERS
}

\author{
MR. HARILAL \& DR. ANUSHA BHASKAR \\ ${ }^{I}$ Research Scholar, Sarvapalli Radhakrishan University, Bhopal and Sri Venkateshwara Research Centre, \\ Thanjavur, Tamil Nadu, India \\ ${ }_{2}^{2}$ Professor, Sarvapalli Radhakrishan University, Bhopal, Madhya Pradesh, India
}

\begin{abstract}
In football players hamstring stains and injuries are the most frequently occurring injuries. They are very challenging to treat and frustrating to both the player and the therapist. Hamstring strain accounts for $12-16 \%$ of all injuries in athletes $(1,2)$ with re-injury rate reported as high as $22-34 \%(3,4)$. A number of risk factors for hamstring injuries include decreased flexibility, strength deficits, poor core stability, and lack of proper warm-up, poor lumbar posture and prior hamstring injury. (5).Hamstring strains can occur during a variety of athletic maneuvers and situations, resulting in several distinct types of injuries, each with a unique mechanism. The first occurs during a stretching of the muscle at extreme joint positions, such as in a Rockette style high kick.(6,7). These injuries generally occur to the proximal free tendon of the semi-membranous tendon and appear to be less severe initially but ultimately require a longer recovery time than hamstrings strained by other mechanisms.(8) The second mechanism of hamstring strain occurs during high speed running. It has been well established in the literature that eccentric training is effective in the prevention of hamstring strains. $(9,10)$. Unfortunately, despite the best prevention programs hamstring strain injuries still occur.

KEYWORDS: Prevention and Rehabilitation, Football Players Hamstring Stains
\end{abstract}

Received: May 09, 2019; Accepted: Jun 29, 2020; Published: Jun 30, 2020; Paper Id.: IJMPERDJUN2020231

\section{INTRODUCTION}

Sampling frame, sample method and sample size, source of data, demographic information, universe of the study, ethical consideration, exclusion and inclusion criteria and data analysis. The sample frame included football players aged 14 to 30 years. The method of sample was purposive - A non-random method of sampling design for football players with a specific purpose. Total of 75 football players from Kerala varsity were selected as sample size of the study. The study depends mainly on primary source of data. The data was collected through respondents in the form of Questionnaires from 275 football players of different colleges who play for various clubs in Kerala. The data was collected through respondents in the form of different descriptive tests. The demographic information about, age, height, weight etc was obtained. These players have been participating in district and state level football matches.

\section{METHODOLOGY}

This study involves a cross-sectional, survey of football players in a non-experimental, retrospective design. Retrospective studies generally related to form of questionnaire and ask respondent to recall injury that occurred in a specific period. This explores and measures the injuries prevalence in football players. This study aims to determine the injuries among football players who are playing the same game and may be helpful to reduce injuries and enhance performance. Ethical guidelines were followed. Participation in this study was strictly 
voluntary.

In the present study, the modified questionnaires made by the Cromwell, Gromely(11) for football players were utilized after the modification of these questionnaries and the test - retest reliability was found to be 0.9 . The questionnaires were divided into two parts. A and B part consisted of questions of the morphological characteristics of the footballers, with the details of height, educational qualification birth order age, weight and height, duration of training, warm up period and number of years of training.

The data collected was analyzed as a whole and fragments. The data was checked for accuracy and completeness and was coded and analyzed using SPSS package.

\section{RESULTS AND DISCUSSIONS}

Table 1: Morphological Characteristics of Players

\begin{tabular}{|l|l|c|}
\hline S. No & \multicolumn{1}{|c|}{ Components } & Values \\
\hline 1. & Age (years) & $25.3 \pm 7.52$ \\
\hline 2. & Weight $(\mathrm{Kg})$ & $67.5 \pm 15.35$ \\
\hline 3. & Height $(\mathrm{cm})$ & $172.5 \pm 45.6$ \\
\hline 4. & Training (days/week) & $4.5 \pm 1.5$ \\
\hline 5. & Training duration (hours) & $2.5 \pm 0.5$ \\
\hline 6. & Warm up (minutes) & $10.0 \pm 2.5$ \\
\hline 7. & Competition in one year & $4.5 \pm 2.0$ \\
\hline
\end{tabular}

Table 2: Players Participating in Other Sports

\begin{tabular}{|c|l|c|}
\hline S. No & \multicolumn{1}{|c|}{ Sports } & Football players (\%) \\
\hline 1. & Volleyball & 14 \\
\hline 2. & Hockey & 15 \\
\hline 3. & Basketball & 12 \\
\hline 4. & Swimming & 10 \\
\hline 5 & Athletics & 17 \\
\hline 6. & Others & 11 \\
\hline
\end{tabular}

Table 3: Percentage of Training by Trained and Self or Untrained Coach Among Foot ballplayers.

\begin{tabular}{|l|l|l|}
\hline \multicolumn{1}{|c|}{ S. No } & \multicolumn{1}{|c|}{ Coaching by } & \multicolumn{1}{c|}{ Percentage } \\
\hline 1. & Trained Coach & $48.2 \%$ \\
\hline 2. & Untrained Coach & $44.2 \%$ \\
\hline 3. & Self & $11.2 \%$ \\
\hline
\end{tabular}

Table 4: Percentage of Feeling Before Competition Among Football Players.

\begin{tabular}{|c|l|c|}
\hline S. No & Psychological Components & Football players (\%) \\
\hline 1. & Relax & $32.4 \%$ \\
\hline 2. & Motivate & $27.52 \%$ \\
\hline 3. & Stressful & $12.5 \%$ \\
\hline 4. & Happy & $14.5 \%$ \\
\hline 5. & Anxious & $9.25 \%$ \\
\hline 6. & Others & $7.85 \%$ \\
\hline
\end{tabular}

Table 5: Percentage of Absentees from Training Due to Injuries Among Football Players

\begin{tabular}{|c|l|c|}
\hline S. No & Percentage & Football players \\
\hline 1. & Absent & $48.25 \%$ \\
\hline 2. & Not absent & $51.8 \%$ \\
\hline
\end{tabular}


Table 6: Percentage of Recommendation of Treatment of Injuries Among Football Players.

\begin{tabular}{|c|l|c|}
\hline S. No & \multicolumn{1}{|c|}{ Recommendation } & Percentage Of Treatment \\
\hline 1. & Doctor & $52.5 \%$ \\
\hline 2. & Physiotherapist & $25.5 \%$ \\
\hline 3. & Others/self & $30.5 \%$ \\
\hline
\end{tabular}

Table 7: Percentage of Mechanism of Injuries of Football Players.

\begin{tabular}{|l|l|c|}
\hline S. No & Mechanism of Injuries & Percentage of Injuries \\
\hline 1. & Stumble & $13.5 \%$ \\
\hline 2. & Tackle & $16.8 \%$ \\
\hline 3. & Collision & $15.25 \%$ \\
\hline 4. & Running & $12.2 \%$ \\
\hline 5. & Twist & $9.25 \%$ \\
\hline 6. & Contact with ball & $7.25 \%$ \\
\hline 7. & Foul play & $10.2 \%$ \\
\hline 8. & Others & $12.5 \%$ \\
\hline
\end{tabular}

Table 8: Percentage of Injury in Different Playing Position Among Age groups of Foot ball Players.

\begin{tabular}{|c|c|c|}
\hline S. No & Location & Percentage Of Injuries \\
\hline 1. & Offender & $45.25 \%$ \\
\hline 2. & Defender & $48.3 \%$ \\
\hline 3. & Midfielder & $20.25 \%$ \\
\hline
\end{tabular}

This is a retrospective study ofinjuries in football players. This study involves the survey of injuries in football players ina non-experimental, retrospective design. This explores and measures the injuriesprevalence in football players.

We have used the modified questionnaires of byCromwell, and Gromely (11)in this study for footballers after the modificationof these questionnaires and the test -retest reliability was educational qualification age, weight, and height training duration, weekly training,found out 0.9 by theresearcher. Questionnaires were distributed to football playerspersonally when they trained in their colleges and stadiums. Instructions were given to the footballersbefore filling these questionnaires by the researcher, football coach and footballexperts. Data was collected individually through a questionnaire from 275 footballplayers. The statistical computation of data of the present study is used by usingSPSS package in the computer.

Total 109 injuries out of 275 football players werefound out over the one year of the period. Table 1 reveals that morphological characteristics of the footballers included in the study. This table also shows the duration of training. The values are represented as mean \pm S.D. other sporting activities of the footballers other than football is shown in table 2.

The result reveals that the mostof the football players have participating in cricket, hockey volleyball andbasketball in any sporting activity other than football more than two hours a weekthis results is in conformity with a study of Jhadav et.al. (12)who concluded that the most of the football players haveparticipating in cricket, volleyball and basketball.

Table 3, shows that the percentage of training by trained and self/untrainedcoach among football players. $48.2 \%$ football players have taken training bytrained coach. While $44.2 \%$ football players taken coaching by the untrained coach and $11.2 \%$ were self- trained.

The psychological evaluation of the football players are shown in table 4, 32.4\% were relaxed, $27.5 \%$ motivated, $14.5 \%$ were happy while $12.5 \%$ and $9.25 \%$ were found to be stressful and anxious. 
Table 5, shows that the percentage of absentees from training due to injuriesamong football players. $48.25 \%$ football players reported absent from training dueto injuries while $51.8 \%$ football players attended training and were not injured.

Table 6 shows the treatment recommendation to the injured players and this also reflects the extent and seriousness of the injury. Doctor attended to 52.5\% of injured players while $25.5 \%$ were attended by physiotherapist and in $30.5 \%$ the injuries are not so severe. This result is also supported by Verma(13) reported thatmaximum injuries treated by the doctor to the sports person.

Keeping in view the fact that injuries have important health consequences duringtheir participation in game, a large number of studies have been reportedfrom different countries of the world. Data on the injuries from England, America Brazil, Ching, Russia and Europe are available in theliterature, all these reports made the football expert realize the play affected dueto injuries of football players.

Hamstrings are most commonly site ofinjuries to footballers. The majority of injuries associated with football sustainedthe in the, knees, groin, and ankles.(14). The most commoncauses of disorders of the knee are: (1) A torn medial meniscus cartilage; (2) Subluxation of the patella; (3) Sprains and tears of the all ligaments in the knee.

There are instances when athletes have more pain at rest and feel better and eveneliminate pain on activity. It is also imperative that in the History taking the painbe described in standard terms, such as sharp, dull, radiating, aching, pressing, orsqueezing.The functions at the foot in stance and motion are primarily stability,support, and secondarily propulsion at body weight under varied conditions. Inorder to function efficiently the structures must work in intricate balance,allowing effortless support, voluntary control, and effectivepropulsion, if this takes place, there is no energy wasted, no friction, extra motion,or protective inefficient activity. Over use implies that when the problems develop,the body is under conditioned.

Two major categories of injuries are common in footballers, thosecaused by imbalance, and those caused by training, imbalance injuries of the footmay be described in terms of the reference planes at the body namely : (1) Saggital; (2) Flexion and extension; (3) Frontal (side to side ) problems, inversion oreversion at the foot and ankle; (4) Transverse (rotational) problems, such as intoe, or out of toe, or secondary knee and hip torsional (twisting) problems. Imbalance of the foot will allow either direct training to the body or the body willcompensate for the imbalance with additional stress in the form of the overuse, such as strain, muscle fatigue, cramps, tendinitis, or the stress fractures.

Table 7, shows that thepercentage of mechanism of injuries among football players. $13.5 \%$ occurrenceof injuries to football players due to Stumble. $16.8 \%$ injuries due to Tackle.15.25\% injuries due to Collision. $12.2 \%$ injuries due to Running. 9.25\% injuriesdue to Twist.7.25\% injuries due to Contact with ball. $10.2 \%$ injuries due toFoul play and $12.5 \%$ injuries occurred due to others Mechanism. Stumble,Collision and Tackle are most occurrences of injuries to football players. Sinku S.K.(15) also reported training related injuries in football players, Basketballers,and Marathon runners and ascribed them to the wrong technique and poor fitnessgroup of athletes.

Table 8, shows that the percentage of injuries in relation to playing position among football players. Offender football players reported their injuries in $45.25 \%$, Defender football players reported their injuries $48.3 \%$, and Midfielder football playersreported their injuries in $20.25 \%$. 
Many risk factors including poor flexibility, strengthimbalance, insufficient warm-up, and fatigue have beenproposed as risk factors for hamstring strain injury. Basicscience studies have established the connections betweenmuscle strain and strain injury, muscle optimum length andmuscle strain, and flexibility and muscle optimum length,which support poor flexibility and insufficient warm-up as riskfactors for hamstring strain injury. However, the theoreticalbasis of hamstring strength imbalance and other proposed riskfactors for hamstring strain injury is lacking.

This study is a preliminary study on the characteristics of the football players and the nature of the injuries they encounter. This may further be extended to give an insight into the prevention of hamstring injury which is very common in these players.

\section{REFERENCES}

1. Brooks JH, Fuller CW, Kemp SP, et al. Incidence, risk, and prevention of hamstring muscle injuries in professional rugby union. Am J Sports Med 2006; 34: 1297-1306 [PubMed]

2. Woods C, Hawkins RD, Maltby S, et al. The Football Association Medical Research Programme: an audit of injuries in professional football - analysis of hamstring injuries. Br J Sports Med 2004; 38: 36-41.

3. Orchard J, Sweard H. Epidemiology of injuries in the Australian Football League, seasons 1997-2000. Br J Sports Med 2002; 36: $39-44$.

4. Malliaropoulos $N$, Isinkaye T, Tsitas $K$, et al. Reinjury after acute posterior thigh muscle injuries in elite track and fi eld athletes. Am J Sports Med 2011; 39: 304-10.

5. Engebretsen AH, Myklebust G, Holme I, et al. Intrinsic risk factors for hamstring injuries among male soccer players: A prospective cohort study. Am J Sports Med 2010; 2010: 1147-53.

6. Askling CM, Tengvar M, Saartok T, et al. Acute fi rst time hamstring strains during slow speed stretching: a clinical, magnetic resonance imaging, and recovery characteristics. Am J Sports Med 2007; 35: 1716-24.

7. Askling CM, Tengvar M, Saartok T, et al. Proximal hamstring strains of stretching type in different sports: injury situations, clinical and magnetic resonance imaging characteristics, and return to sport. Am J Sports Med 2008; 36: 1799-804.

8. Askling CM, Saartok T, Thortensson et al. Type of acute hamstring strain affects flexibility, strength, and time to return to preinjury level. Br J Sports Med 2006; 40: 40-44.

9. Heidercheit BC, Sherry MA, Silder A, et al. Hamstring strain injuries: recommendations for diagnosis, rehabilitation, and injury prevention. J Orthop Sports PhysTher 2010; 40: 67-81.

10. Kalli K and Stasinopoulos D, 2014. Hamstring injuries: Prevention and recovery. Med News 16-23, 2014 (In Greek).

11. Cromwell, F.J. and Gromely, W. 2000. A Pilot Study examining injuries in elite Gaelic footballers. British Journals of Sports Medicine, 34: 104-108.

12. Jadhav, K.G ;Deshmukh, P.N ; Tuppekar, R.P ; Sinku, S.K (2010). A Survey of Injuries Prevalence in Varsity Volleyball Players. Journal of Exercise Science and Physiotherapy, Vol. 6, No. 2: 102-105

13. Verma, J.Hemant; and Lathi, R. Kanchan (2010). Injury Occurrence to Elite Level Women Volleyball Players. International Research Journal, Vol.1 pp 85-88.

14. Sinku S.K.( 2006) “Injury of swimmers” Indian journal of sports study Vol.6 40-44.

15. Shinku S.K (2008) Comparison of Occurrence of Injuries to Footballers at Low and High Level of Achievement. Journal of 
Exercise Science and Physiotherapy, Vol. 4, No. 2: 109-114.

16. Sudhakar, S., and G. MOHAN Kumar. "To compare the effects of static stretching and eccentric training on hamstring flexibility in collegiate male athletes." International Journal of Physiotherapy\& Occupational Therapy (TJPRC: IJPOT) 2.2 (2016): 39-44.

17. Sudhakar, S., And Cv Senthil Nathan. "Effects Of Deep Stripping Massage With Eccentric Resistance Versus Static Stretch With Cryotherapy On Improving Calf Muscle Flexibility." International Journal Of Physiotherapy\& Occupational Therapy (Tjprc: Ijpot) 2.2 (2016):45-50

18. Salimin, Norkhalid, Julismah Jani, And Gunathevan Elumalai. "Now The "Boys Turn": Using Comprehensive Assessment For Handball In Physical Education." International Journal Of Educational Science And Research (Ijesr) 4.5 (2014):9-18

19. V Thomas, George. "Comparative Analysis On Selected Psychological Characteristics Among Cricket Players And Non Cricket Players." IMPACT: International Journal Of Research In Humanities, Arts And Literature (IMPACT: IJRHAL) 5.12 (2017): 63-66.

20. Sudhakar, S., Et Al. "Efficacy Of 6 Week Plyometric Training On Agility Performance In Collegiate Male Basketball Players." International Journal Of Physiotherapy \& Occupational Therapy (TJPRC: IJPOT) 2.2 (2016): 1-8.

21. Arjunan, R. "Effect Of Circuit Training And Anaerobic Interval Training On Speed And Strength Among Men Handball Players." International Journal Of Humanities, Arts, Medicine And Sciences (Best: Ijhams) 3.10 (2015):75-80

22. Arjunan, R. "Effect Of Rope Skipping Dands And Baithaks Exercises On Selected Physical Fitness Variables Among Kabaddi Players." International Journal Of Humanities, Arts, Medicine And Sciences (Best: Ijhams) 3.10 (2015):69-74

23. Javed, Saeed, Abd Rahim Bin Mohd Shariff, And Shanmuga Nathan. "Influences Of Hockey Coaches, Team Cohesion And Motivational Intensity On The Performance Of Pakistani Field Hockey Players." International Journal Of Humanities, Arts, Medicine And Sciences (BEST: IJHAMS) 3.3 (2015):53-62 